\title{
Baubo: a Case of Ambiguous Genitalia in the Eleusinian Mysteries
}

\author{
Neoklis A Georgopoulos ${ }^{1}$, George A Vagenakis ${ }^{2}$, Apostolos L Pierris ${ }^{3}$
}

Division of Reproductive Endocrinology, Department of Obstetrics and Gynecology ${ }^{1}$, Department of Internal
Medicine, Division of Endocrinology ${ }^{2}$, University of Patras Medical School, Philosopher

Key words: Baubo, ambiguous genitalia, hermaphrodism, congenital adrenal hyperplasia, Eleusis, Orphism.

\section{THE BAUBO EPISODE IN THE ORPHIC- ELEUSINIAN FOUNDATION MYTH: TEXTUAL EVIDENCE}

In an Orphic account of the constitutive mythology of the Eleusinian Mysteries, there occurs the relation of a remarkable tale of sacred obscenity. The Baubo affair is pivotal for a more in-depth understanding of the symbolism involved in the most awesome mysteric cult of the ancient Greek world. For it is there that is revealed what occasioned the change in Demeter's attitude regarding her daughter Persephone's rape. Our main sources for this event are two Church Fathers, Clemens of Alexandria ${ }^{1}$ and Arnobius ${ }^{2}$. The relevant passages can be conveniently consulted in $\mathrm{O}$. Kern, Orphicorum Fragmenta, Fr. 52.

Kore (= Persephone) has been abducted and raped by Pluto (= Hades), the Lord of the Underworld.

Address correspondence and requests for reprints to: Neoklis A. Georgopoulos, Department of Obstetrics and Gynecology, Division of Reproductive Endocrinology, University of Patras Medical School, Rio 26500, Greece, Tel: 2610-999835, Fax: 2610-993854, e-mail: neoklisg@hol.gr, Apostolos L. Pierris: Philosopher, Kolokotroni 42, Patras 26221, Greece, Tel:2610-241068, Fax:2610-271269, email:pierrisapost@hotmail.com

Received 03-11-02, Revised 27-12-02, Accepted 03-01-03
Demeter wanders over the wide earth, sorrowful and lamenting, in search of her. Her quest is in vain. The great Goddess finally arrives at Eleusis and sits, unrecognized, grief-stricken by a subsequently sacred well. She encounters local people there and is particularly hospitably entertained by a woman called Baubo.

According to another version of the Orphic testimony $^{3}$, which may indeed constitute the framework

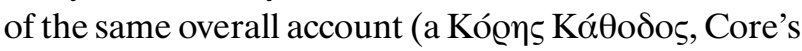
Descent) into which the Baubo episode is inscribed, Baubo is the local queen, wife of Celeus and mother of Demophoon. Alternative traditions make the Eleusinian $\mathrm{King}^{4}$, who, for standard Orphism, is father of Eubuleus and Triptolemus ${ }^{5}$, divine and heroic figures respectively, of crucial importance for the Mysteries. Some reports ${ }^{6}$ make Dysaules husband of Baudo. Their offsprings are then Protonoe and Misa, daughters personifying Primal Intelligence and Sexual Lewdness respectively. Dysaules is (as we shall see) an appropriate partner to Baubo, given the connotation of sexual malformation in his membrum virile which his

\footnotetext{
* This paper is a selective précis from a forthcoming full study of the Baubo affair in all its aspects philological, medical, religious and philosophical. Parts I and III were written by A.L. Pierris; part II from N.A. Georgopoulos and G.A. Vagenakis.
} 


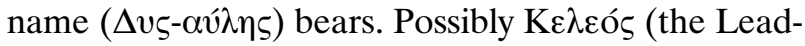
er?) and $\Delta v \sigma \alpha v i \lambda \eta \varsigma$ (the Malphallic) are names referring to the same person under his different attributes.

To return to the main incident in question, Baubo in vain tries to revivify and console Deo $(\Delta \eta \omega$, the Seeking One $=$ Demeter). The Goddess persists in her despondency. She fasts and mourns; she even re-

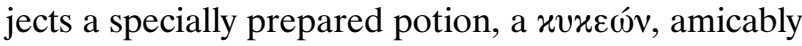
offered to her by Baubo. The drink will become something akin to a holy communion in the Eleusinian Mysteries.

When everything else fails, Baubo resorts to the last expedient she can summon in order to revitalize the disconsolate Demeter. Here follows in our Christian sources the Orphic poetic fragment. Clemens has it thus, according to the transmitted text with minor corrections ${ }^{7}$ :

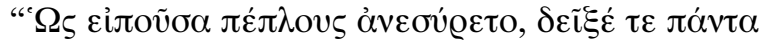

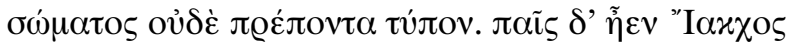

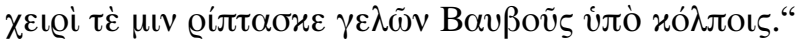

"Having said so, she pulled up her dress, and revealed completely

the unbefitting form of her nature; there was a child, Iacchos,'

and with his hand he, laughing, tossed and jerked it under Baubo's womb.“

(The text has been widely held to be corrupt in the third verse, and numerous emendations have been suggested in correction, yielding variant meanings). Arnobius' version on the other hand is this(in translation from the Latin) ${ }^{8}$ :

"Having said so, she at once drew up her garments from down below

and revealed to the sight the form of her privy parts; which Baubo tossing with hollow hand - for their appearance was puerile - strikes, handles caressingly".

Baubo's purpose is thereby achieved: the Goddess brightens, laughs - and drinks the potion. As Arnobius ${ }^{9}$ puts it: "and the indecency of a shameless action forced that which Baubo's modest conduct was long unable to win".

What exactly constituted the sight and act which was of such portentous significance that enabled Demeter to overcome her grief at the rape and loss of her divine daughter? Arnobius (despite the rhetorical exaggeration of his highly ornamental style, the so-called African oratory) is clear in his explanatory remarks. Baubo's pudenda had the shape of a "nondum duri atque hystriculi pusionis" ${ }^{10}$ : the form was like that of "a little boy's, not yet hard and rough with hair". This can explain the wondrous change in Demeter's attitude. For as Arnobius emphasizes ${ }^{11}$ : "what was there in Baubo's pudenda to move to wonder and laughter a goddess of the same sex, and formed with similar parts? What was there such that, when presented to the divine eyes and sight, it should enable her to forget her miseries and bring her with sudden cheerfulness to a happier state of mind?". It is now evident that the "unbefitting form" in Baubo's womb according to the Clementine fragment was not unseemly and indecent in an immoral sense, but "inappropriate (to a woman)", "inapposite", "inapt".

For reasons that will be analyzed in the forthcoming full study of the subject, what best accords with the religious, mythological and ritual context is the assumption of the appearance of a puerile membrum virile in Baubo's womb. She herself played with it. In such an approach, Clemens' Iacchus (if this name, as is more likely, is sound and we do not really need another emendation here) should be construed symbolically. Furthermore, the Clementine text should be emended in the third verse to yield the required meaning. The sense must be that Baubo handled what appeared as a childlike membrum virile in her womb. In this direction D. Heinsius $\left(17^{\text {th }}\right.$ century) already proposed $^{12}$ :

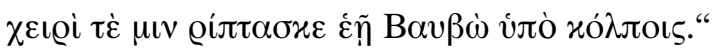

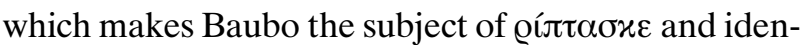

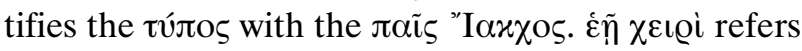
to her own hand. Similarly Jacobi ${ }^{13}$ suggested:

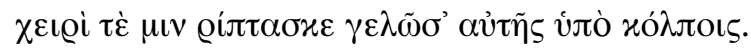

again to the same effect. $\Gamma \varepsilon \lambda \tilde{\omega} \sigma \alpha$ sc. Baubo. One may envisage also:

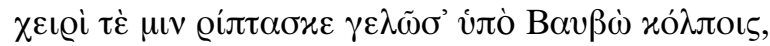

where the daring hyperbaton and the unusual scanning (spondee in the fifth foot) might have contributed to the manuscript miscorrection. The meaning in any such case would then be:

"and with her hand Baubo, laughing, tossed and jerked 
it (sc. the $\tau$ ช́лo $\varsigma$ = Iacchus) under (her) womb". (It may after all not be without significance, also in this connection that Dionysius the Elder, Syracusan tyrant and tragic poet, used the word Iachos to mean the pig. Xó́oos (pig) was an idiomatic name for the female pudendum $)^{14}$.

It was something like a little prepubertal phallus which layed encompassed between Baubo's external genitalia.

\section{MEDICAL INTERPRETATION OF BAUBO'S MYTH}

Baubo was a female with ambiguous genitalia. Her appearance was that of a female, while her external genitalia presented elements of both sexes, both a vulva and a juvenile phallus. This phallus could be either a juvenile penis or an enlarged clitoris.

We can speculate therefore that Baubo was a case of hermaphroditism, either true or pseudohermaphrodism. We know from the myth that Baubo was married and mother of one or two children. Being therefore able to get pregnant and deliver a child means that her internal genitalia were intact and functional. Thus the uterus, the tubes and the ovaries should be normal while the external genitalia should appear masculinized. Therefore, Baubo could not be a case of male pseudohermaphrodism.

Baubo was therefore either a case of true hermaphrodism or a case of female pseudohermaphrodism.

In true hermaphroditism the appearance of the external genitalia may simulate those of a male (phallus) or female or may be ambiguous ${ }^{15}$. Breast development and menses are common. Ovulation on the other hand is not uncommon and pregnancy with successful childbirth has been reported ${ }^{15-17}$ in true hermaphrodites with 46, XX karyotype. Still, true hermaphrodism is a very rare disorder and successful childbirth is an extreme exception. Therefore, we can speculate that Baubo might have been an extremely rare case of a true hermaphrodite who was able to give birth and had the appearance of both a male (phallus) and female (breasts and nonfused labiosacral folds). Both Arnobius and Clemens insisted in their description of Baubo's external genitalia on their juvenile appearance. Baubo's pudenda had the shape of a "nondum duri atque hystriculi pusionis - a little boy's, not yet hard and rough with hair" according to Arnobius, while it looked like a " $\pi \alpha i \varsigma$-child" according to Clemens. All these descriptions point towards the presence of an enlarged clitoris rather than a true penis in Baubo's external genitalia, a finding characteristic of a female pseudohermaphrodite rather than a true hermaphrodite.

Female pseudohermaphroditism is another possible diagnosis. The external genitalia in such a case appear virilised to varying degrees from a mildly enlarged clitoris to an organ indistinguishable from a penis. The degree of virilization is determined by the time and extent of androgen exposure.

Female pseudohermaphrodism is mainly caused by different forms of congenital adrenal hyperplasia $(\mathrm{CAH})$, the commonest disorder of sexual differentiation $^{18,19}$. New and Kitzinger attributed the medieval legend of Pope Joan, a Roman Pope who was supposed to have conceived and delivered a child, to a case of ambiguous genitalia similar to $\mathrm{Baubo}^{20}$. The legend formed the basis of a famous novel by Emmanuel Roidis in the last century ${ }^{20}$.

In the non-classical form of $\mathrm{CAH}$, the appearance of the external genitalia is that of a female without signs of masculinization. Affected females have no or very mild genital ambiguity, whereas we know that Baubo had an enlarged clitoris or phallus.

Baubo would, therefore, most probably be a case of the simple virilizing form of $\mathrm{CAH}$, without glucocorticoid and mineralocorticoid deficiency but masculinized external genitalia due to clitoris enlargement. It is known that such cases could have normal reproductive function and pregnancy.

\section{THE MEANING OF THE SYMBOLISM IN BAUBO'S MYTH}

Hermaphroditism is replete with religious significance in ancient cultures. Remaining within the early Orphic sphere, the very origin of world-creation is defined by the emergence of Phanes as the First- Born.

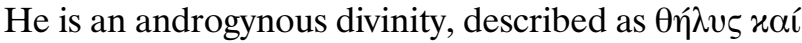
$\gamma \varepsilon v \varepsilon ́ \tau \omega \mathrm{Q}$, female being and (male) begetter ${ }^{21}$. As another Church Father, Lactantius, aptly explains (in translation from the Latin) ${ }^{22}$ : ...(unless we estimate that) god, as Orpheus has maintained, is both male and female, because otherwise he might not be able to generate, unless he had the force of both sexes, and either he must copulate with himself or be powerless without coition to procreate". Phanes is invoked

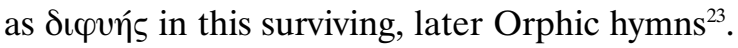

The Creator-God Zeus, the Orphic creative divin- 
ity par excellence, is also adored as simultaneously Male and Immortal Bride in the famous extant Hymn $^{24}$ :

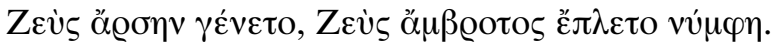

In the Baubo account, however, her ambiguous pudenda rendered explicit the unity of sexes: that the different formations characterizing the male and female nature are fundamentally the same. In the cosmic womb, the penetration is complete, to the point of fusion. And this is a potent index of the identity of opposites in general. Differentiation is a tension within the same thing that is bound to be resolved eventually into the re-affirmation of its underlying unity. In the context of such Proto-Heracletianism, we may understand Demeter's otherwise miraculous emotional change at the sight of Baubo's genitalia.

Rape is the (re)integration of the aboriginal and fundamental sexual whole-ness. What has been separated reunites in coition. By the same token chthonic darkness and celestial light come ultimately to the same reality, as do death and life. Death is (re)birth. Universal cyclicity ensures eternity. Kore lives for ever, eternally reconstituted in her Virginity through never-ceasing copulation, remaining in actuality unraped by Malehood and Death in the midst of total rape. Even more, malehood emerges from the womb of Urfeminity. Similarly, death is a modification of life, not the other way round. One pole in the pair of opposites enjoys a certain priority, in that it better expresses the original unity. Demeter has no reason to grieve anymore for the loss of her daughter. Truth came to her in a flash from Baubo's genitalia.

Harmony reigns supreme amidst the apparent chaos of discord and disorder.

\section{REFERENCES}

1. Clemens Alexandrinus, Protrepticus II. 20, 1-21, 2, Stählin pp, 15-16.

2. Arnobius, Adversus Nationes V 24-26, Reifferscheid pp, 195-199.

3. Kern, Orphicorum Fragmenta Fr. 51.

4. Palaephatos, Fr. Gr. H. 44F1. (F. Jacoby, Die Fragmente der Griechischen Historiker)

5. Pausanias I, 14, 3 .

6. Asclepiades, Fr. Gr. H.12F4.

7. Clemens, op. cit. II, 21, 1.

8. Clemens, op. cit. V 26.

9. Arnobius, op. cit. p, 197.8-9 R.

10. Arnobius, op. cit. p, 197.2-3 R.

11. Arnobius, op. cit. p, 198.22-199.3.

12. D. Heinsius' first edition of Clemens appeared in 1616. His note to the Orphic fragment may be consulted in Potterus' variorum edition of Clemens (1715).

13. E. Jacobi, 1847 Handwörterbuch der griechischen und römischen Mythologie. p, 185 n. ${ }^{*}$

14. Athanis, Fr. Gr. H. 562F1.

15. Williamson HO, Phansey SA, Mathur RS 1981 True hermaphroditism with term vaginal delivery and a review Am J Obstet Gynecol 141: 262-265.

16. Starceski PJ, Sieber WK, Lee PA, 1988 Fertility in true hermaphrodism. Adolesc Pediatr Gynecol 1:155-156.

17. Shannon R, Nicolaides NJ 1973 True hermaphroditism with oogenesis and spermatogenesis. Aust $\mathrm{N}$ Z J Obstet Gynecol 13: 184-187.

18. New MI 1998. Inborn errors of steroidogenesis. Steroids 63: 238-241.

19. Dacou-Voutetakis C, Maniati-Christidi M and Dracopoulou-Vabouli M 2001 Genetic aspects of congenital adrenal hyperplasis 14 suppl 5: 1303-1308.

20. New MI, Kitzinger ES 1993. Pope Joan: a recognizable syndrome. J Clin Endocrinol Metab 76: 3-13.

21. Kern $O F$, Fr. 81. Cf. also Fr. 80.

22. Lactantius, Divinae Institutiones IV , 8, 4 p, 296. 2 Brandt.

23. Hymni Orphici, VI, 1.

24. Kern, OF, Fr. 168.3. 